\title{
Social Medial Promotional Activities Influence on Purchase Choice Decision and Price of Perishable Food Items during COVID-19 in Lagos, Nigeria
}

\author{
Scholastica Ebarefimia Udegbe and Azeez Adekunle Aliu
}

\section{ABSTRACT}

\begin{abstract}
This study aimed to research if promotional activities on social media influence purchase choice decisions, consumers impulse buying, the price for perishable food items, like vegetables, fruits, beef, fish, and others during the COVID-19 pandemics. Likewise, if there are differences between the original market price of goods before the COVID-19 pandemic and the promotional online prices during the pandemic, to investigate if the online price of delivering goods to consumer homes influence consumer quantity purchase decision, and if there is any relationship between consumer location and price of goods delivery during the COVID-19 pandemics. The results suggest that promotional activities on social media for perishable food items during the pandemic does not necessarily influence consumers purchase choice decision, but rather, influence consumer quantity purchase, and there is a difference between the original market price of goods before the COVID-19 - pandemic and the promotional online price during the pandemic. Likewise, there is a relationship between consumer location and price of goods delivery during the COVID-19 pandemics. The findings of the study showcase a typical situation of things during a crisis in a developing country, where people take advantage of situations to exploit the helpless. Prices of goods increased, and people had no choice but had to buy because man cannot do without food.
\end{abstract}

Keywords: COVID-19, Perishable Goods Prices, Purchase Choice Decision, Social Media Promotional Activities.

\section{INTRODUCTION}

At the beginning of 2020, a global crisis struck the world in the form of COVID-19 pandemics, and Nigeria was no exception. The pandemic caused room for change in consumer buying behavior due to lockdown, social distancing and new regulations by the government related to shopping at the shopping centers, markets, air travel, attending concerts, sports, and among others. As a result of all these regulations, a consumer realized that going to a store in person is much of a big hassle, therefore, it's easier and more convenient to let the store come to the home. Hence, to meet the needs and wants of consumers while staying at home, most consumers had to embrace digital technology out of sheer necessity, in this way, resulted in online search and online ordering through social media. However, this study aimed to research if promotional activities on social media influence purchase choice decision, consumers' impulse buying, and price for perishable food items, like vegetables, fruits, beef, fish, and among others during the COVID-19 pandemics. Likewise, if there are differences between the original market price of goods before the COVID-19 pandemic and the promotional online prices during the pandemic. This also investigate if the online price of delivering goods to consumer homes influence consumer quantity purchase decision, and if there is any 19 pandemics.

\author{
Submitted : July 11, 2021 \\ Published : August 09, 2021 \\ ISSN: 2507-1076 \\ DOI: $10.24018 /$ ejbmr.2021.6.4.981 \\ S. E. Udegbe \\ Contemporary Business Issues Academic \\ Research Group, Lagos, Nigeria. \\ (e-mail: scholasticudegbe ${ }^{@}$ yahoo.co.uk) \\ A. A. Aliu* \\ The Federal Polytechnic, Ilaro, Ogun State, \\ Nigeria. \\ (e-mail: azeez.aliu@ federalpolyilaro.edu.ng)
}

*Corresponding Author

relationship between consumer location and price of goods delivery during the COVID-19 pandemics. This study also adds to earlier works of literature.

This paper begins with a focus on the objective of the study and then a short literature review to define where the paper aims at contributing to past literature. It then moves on to the research method and hypothesis. The findings from the study are further analyzed in the results section and followed by the implications for theory and practice as described in the conclusion and future recommendations.

\section{A. Objectives of the Study}

1. To find out if promotional activities on social medial influence purchase choice decisions for perishable food items, like vegetables, fruits, beef, fish, and others during the COVID-19 pandemics.

2. To find out if promotional activities on social medial causes impulse buying for perishable food items, like vegetables, fruits, beef, fish, and others during the COVID-

3. To find out if promotional activities on social medial influence price for perishable food items, like vegetables, fruits, beef, fish, and others during the COVID-19 pandemics.

4. To find out if there are differences between original market prices of goods before the COVID-19 pandemics and 
the promotional online prices during the pandemic

5. To investigate if the online price of delivering goods to consumer homes influence consumer quantity purchase decision during the COVID-19 pandemics.

6. To investigate if there is any relationship between consumer location and price of goods during the COVID-19 pandemics.

7. To investigate if there is any relationship between consumer location and delivery price during the COVID-19 pandemics.

The following hypotheses stated in the null form were formulated and tested to achieve the objectives of this study.

H01: Promotional activities on social medial have no significant influence on purchase choice decisions for perishable food items, like vegetables, fruits, beef, fish, and others during the COVID-19 pandemics.

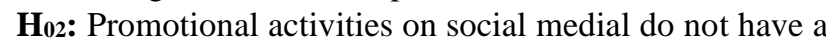
significant influence on impulse buying for perishable food items, like vegetables, fruits, beef, fish, and others during the COVID-19 pandemics.

H03: Promotional activities on social medial have no significant influence on the price for perishable food items, like vegetables, fruits, beef, fish, and others during the COVID-19 pandemics.

H04: There are no significant differences between the original market prices of goods before the COVID-19 pandemics and the promotional online prices during the pandemic

H05: The online price of delivering goods to consumer homes does not have a significant influence on consumer quantity purchase decisions during the COVID-19 pandemics.

Ho6: There is no significant relationship between consumer location and the online price of goods during the COVID-19 pandemics.

H07: There are no significant relationship differences between consumer location and delivery price during the COVID-19 pandemics.

\section{LITERATURE REVIEW}

The outbreak of (COVID-19) pandemics has made diverse countries around the world face varying challenges, from overwhelmed healthcare systems to growing economic, educational, and sustainability despairs. In Nigeria, the COVID-19 pandemic and the lockdown mandates have disrupted the consumer habits of buying, cooking, and as well as eating habits of households. Consumers are learning to improvise and acquire modern habits. Recent research [1] indicates that due to complete lockdown in countries like India, South Korea, China, Italy, and other nations, consumers are unable to go to the grocery store or shopping centers. Alternatively, the store comes home. Consumers under the lockdown condition have discovered a more convenient and accessible alternative. Consumers learn to develop new shopping routines due to crises like COVID-19. Likewise, out of sheer necessity, consumers have adopted several new technologies and their applications by embracing digital technology. Just as consumers have learned to improvise, the business also has to learn to improvise and become more resident during the pandemic crisis. Companies learn how to make their systems and processes to be more resilient; and in the process, manage global crises such as the COVID-19.

According to [2] consumer buying behavior remains a collection of decision processes and later behaviors. It could be planned and unplanned. However, it is determined by internal and external factors based on risk and uncertainty. And the key components in a risk-related crisis are driven by different factors for different consumer segments. They state further that consumers can be segmented into four, the panicked consumers, the prudent consumers, the concerned consumers, and the rational consumers. In crises, the panicked consumer tends to overreact and drastically cut spending, where the prudent consumer carefully plans to spend and postpones major purchases. The concerned consumers also plan their spending carefully, staying loyal to certain brands, but they may be ready to try new and creative products, despite the hard times. While the rational consumers, in turn, are not risk-averse, and their behavior stays essentially unchanged. However, consumer behavior in crises is not always consistent with the true level of risks, and therefore, the first stages of a crisis may witness extreme behavior, which then gradually turns into more normalized behavior or possibly a "new-normal behavior." Panic as a state of intense fear and high arousal may trigger major changes in consumer behavior.

Since the start of stay-at-home orders and the pandemic news frenzy, food has been a frequent, varied topic of conversation. More than half of the families' purchase and eating habits have changed in the time they have been staying at home. With lockdown and social distancing, consumers' choice of the place to shop is restricted. This has resulted in location constraints and location shortage. We have mobility shifts and mobility shortages. Working, schooling, and shopping all have shifted and localized at home. At the same time, there is more time flexibility as consumers do not have to follow schedules planned for going to work or to school or to shop or to eat.

Out of sheer necessity, consumers have adopted several modern technologies and their applications. The obvious example is social media online buying. Just to keep up with family needs and wants, most households with the internet have learned to participate in social media.

Consumers learn to improvise when there are constraints. In the process, existing habits are discarded and new ways to consume are invented. The coronavirus gave room for the creativity of improvisation, where the consumer develops solutions that work by overcoming constraints imposed by the pandemic or government policy.

According to several studies [3], [4] work culture is becoming $24 / 7$ in the current digital era due to working from home. This has given rise to promotional activities, online shopping, convenience living, and others. And many authors have documented that the importance of social media has increased, especially since people have been confined to their homes due to the COVID-19 pandemic [3], [4]. People now place an order for their needs and want items over the internet from the convenience of their own home, which has given rise to the increased need for inventory management and computerized vending machines to accommodate larger orders. 
Most consumers like social media including Facebook, WhatsApp, YouTube, WeChat, Linkedin, and others. Social media is a rich medium for sharing information. This has dramatically changed the nature and scope of word of mouth advice and recommendations as well as sharing information. One of the fastest-growing areas is influencer marketers. Social media has a great influence on consumer behavior and consumer's daily life. Promotional activities on social media influence purchase choice decisions, by helping to transform wants into needs, help develop new habits such as online shopping. Stores had to come home due to a complete lockdown in countries. Consumers are unable to go to the grocery store or the shopping centers. Alternatively, the store comes home. This reverses the flow of purchasing. Promotional activities and home delivery enhance convenience in consumer purchase behavior [5]-[7]. Promotional activities are social motivation and social influencers [8], [9].

Based on extant literature, some researchers [5]-[7], [9] stated that social media enhanced information sharing among consumers through online rating, sponsored ads, and online reviews. Social media has increased online purchasing behavior, therefore many businesses and consumers are engaged. It facilitates to take optimal buying decisions, social motivation, and social influencers.

According to [10] many public messages are sent on social media during the pandemic to raise awareness. During the pandemic, as many countries took measures to increase social distances, hence, the role of social media for engaging and exchanging information among people increased. Social media provides many communication features which increased the pressure on supermarkets and suppliers around the globe to promote their products. Therefore, it is essential to understand the role of social media in helping to meet the needs of consumers even when they remain at home.

At present, the use of social media has increased because people can collect helpful information through local virtual communities on Facebook, WhatsApp, and other social platforms. It has been found that natural disasters and risks situation are strongly associated with supplier demand and consumer reactions [11], [12] therefore, consumer buying behavior is different and unpredictable.

According to [1] one of the immediate effects of the COVID-19 pandemic on consumption and consumer behavior is hoarding. Consumers are stockpiling essential products for daily consumption resulting in temporary stockouts and shortages. In addition to hoarding, there is also the emergence of the gray market where unauthorized middlemen hoard the product and increase the prices. Nonetheless, it is believed that price sensitivity has an impact on changes in buying behavior, which is in line with what has been reported in Sweden, that consumers have noticed the price increases in fruits and vegetables due to the pandemic [13]. Applied to the current pandemic, studies are showing that consumers are buying products for quality and safety assurance, such as hygiene products and canned food, the consumers are also ready to pay a higher price for quality assurance and safety verification in food products [14].

According to the extant literature, consumers seem to be more concerned about prices and offers, rather than the quality of the food in a financial crisis as opposed to a health crisis where consumers were more concerned about food quality than the price [15], [16]. As an example, the BSE crisis, also known as mad cow disease, was a health crisis that struck Europe during the 1980s and 1990s as cows developed a deadly disease that could be transferred to humans by eating fresh beef. The crisis affected the consumers' perception of the quality of fresh beef forever as higher demand on quality controls were introduced and beef was avoided until stricter quality controls were performed [15], [17]-[19]. Even though, it can be seen that the buying behavior of the consumers changes in a crisis, it is significant to stress that the same findings from previous crises cannot be applied to the current situation of the global pandemic. For instance [20] explains that there are big differences in the current pandemic compared to the global financial crisis of 2008-09. The current COVID-19 pandemic has immediately directly affected companies and households that now face threats of bankruptcies and increased unemployment on a greater scale. Economists believe the pandemic could lead to a greater recession than the financial crisis in 2008. In addition, compared to other crises, the pandemic has led to a global and sudden standstill, which makes it unique compared to any other previous crisis in modern times [21]. In comparison to other health crises, the COVID-19 is spreading through communities' way easier and has a higher reproduction number. Compared to the swine flu in 2009-10, the reproduction number was 1.4-1.6, while the COVID-19 number is $2-2.5$ or even higher [22], [23]. So, a situation similar to the COVID-19 pandemic has never been researched before, which creates a research challenge,

COVID-19 has led to changes in consumer behavior patterns, but there has also been a shift in what factors are influencing the decision-making process.

\section{RESEARCH METHODS}

This study used the primary data for the survey. The primary data were collected from the online survey of married women in Lagos State, Nigeria.

The present study has selected married women in Lagos State because women in most cases are in charge of food buying and cooking in their homes in Nigeria. Other criteria are based on the following inclusion:

- Married women over 21 years of age.

- Married women that have used social media platforms for a minimum of two years.

- Married women that must have a minimum of one active social media account.

- Married women that will voluntarily offer research data.

The purposive sampling technique is used in this survey. As postulated by [24], this technique is commonly used by the researcher because it is useful, especially when the researcher does not know the sampling framework but tries to select respondents who have useful knowledge about the objectives of research study 'Therefore, the present study selected the purposive sampling technique and collected data from 100 respondents. The demographic features of targeted respondents are given in Table I.

The sample used for this study was a purposive sampling technique of a self-administered survey by Google forms submitted to the Facebook pages of 60 women that were 
known to the researcher already and the rest 40 of the forms were distributed randomly to various online married women in Lagos State, Nigeria. A total of 100 potential married women respondents are included in the sample size

Before the real study, the researcher conducted a pilot study with 10 respondents. The purpose of this survey is to check the reliability of the questionnaires. Out of the 100 questionnaires that the researcher distributed among the respondents, 79 completed questionnaires were returned. However, 76 copies were found usable for the study, resulting in an effective response rate of $76 \%$.

The questions in the research instruments contain two parts. The first part measured the perception of married women in Lagos State, Nigeria, on food buying behavior of the family during the COVID-19 pandemic lockdown, and the second part recorded respondents' demographic information like marital status, age, level, and family social class. In this study, the researcher has decided to take a fivepoint Likert scale. "Not at all" (1), once in a while (2), sometimes (3), fairly often (4), and "Frequently, if not always" (5) to confirm the hypotheses. Data were analyzed using descriptive statistics, percentages, and t-test analyses.

The research instrument showed high reliability and validity, and the Cronbach alpha reliability coefficient measured $=.0 .8356$. This surpasses the value of 0.70 , in this way suggesting adequate reliability [25].

The opinions of scholars of management and marketing confirmed the content validity of the measures used, while the pilot study result confirmed their predictive validity.

\section{FINDINGS AND DISCUSSION}

The purpose of this study is to look at social media promotional activities' influence on purchase choice decision and price of perishable food items during the COVID-19 pandemics in Lagos State, Nigeria.

\section{Key to research variables used}

A1: Promotional activities on social medial have a significant influence on purchase choice decisions for perishable food items, like vegetables, fruits, beef, fish, and others during the COVID-19 pandemics.

A2: Promotional activities on social medial cause impulse buying for perishable food items, like vegetables, fruits, beef, fish, and others during the COVID-19 pandemics.

A3: Promotional activities on social media significantly affect the price of food items during the COVID-19 pandemics.

A4: Promotional activities on social medial have a significant influence on the purchase price for perishable food items, like vegetables, fruits, beef, fish, and others during the COVID-19 pandemics.

A5: There are significant differences between the original market prices of goods before the COVID-19 pandemics and the promotional online prices during the pandemic.

A6: The online price of bringing goods to consumer homes influence consumer quantity purchase decision.

A7: There is a significant relationship between consumer location and the online price of goods during the COVID-19 pandemics.
A8: There are significant differences between consumer location and delivery price during the COVID-19 pandemics.

\section{A. Demographic Information of the Respondents}

The demographic information got shows that from gender information. $100 \%$ of respondents were female. The main reason for this is only married women were given the questionnaires.

The respondent's age-group information shows that age group ( 21 to 40 years) accounted for $58 \%$ and the next 41 to 60 -years age group accounted for $36 \%$ and above 61 years age group respondents were $6 \%$.

The survey shows that even though the respondents are married women, some have another income source apart from being a housewife. Some of them are students as well as being gainfully employed. The respondents' data shows that $84 \%$ of the respondents earn annual income even though they are married women and $16 \%$ do not but depending on their husband's income.

TABLE I: DESCRIPTIVE STATISTICS OF SOCIAL MEDIAL PROMOTIONAL ACTIVITIES INFLUENCE ON PURCHASE CHOICE DECISION AND PRICE OF Perishable FoOd ITEMS DuRING COVID-19 PANDEMIC IN LAGOS STATE,

\begin{tabular}{cccc}
\multicolumn{4}{c}{ NIGERIA MEASURES (N =76) } \\
\hline \hline Variable & Mean & STD DEV & Skewness \\
\hline A1 & 4.047 & 0.5813 & -0.0762 \\
A2 & 4.034 & 0.5216 & -0.0641 \\
A3 & 4.662 & 0.6016 & -0.0948 \\
A4 & 4.792 & 0.8114 & -0.1027 \\
A5 & 6.241 & 1.9402 & -1.5026 \\
A6 & 4.913 & 1.1068 & -1.1196 \\
A7 & 5.136 & 1.3101 & -1.2081 \\
A8 & 5.582 & 1.4013 & -1.2022 \\
\hline \hline
\end{tabular}

From the mean values in Table I, it can be seen that all the variables (A1-A8) saw a certain degree of support to the statement asked, and A5 (A5 - There are significant differences between the original market price of goods before the COVID-19 pandemic and the promotional online prices during the pandemic) with a mean value of 6.241 demonstrating the most significant extent of support to the statement asked, that there are significant differences between the original market price of goods before the COVID-19 pandemic and the promotional online prices during the pandemic. This is supported by [13] which state that consumers have noticed the price increases in fruits and vegetables due to the pandemic.

Likewise, with the generation from the mean value, A 8 followed respectively with a mean value of 5.582 (A8. There are significant differences between consumer location and delivery price during the COVID-19 pandemics).

From a personal interview conducted it was discovered that the most important attribute considered before buying are price, the consumer location, and cost of delivery. Almost all the women agreed to the question, saying that the dispatch rider bringing the goods home charge based on the distance of the buyer home from the shop, and if UBA or Taxify commercial vehicles are used, customer pay based on the meter readings, which is also a reflection of the distance of the shop to the customer home or place of delivery.

Likewise, Variables A2 (A2: Promotional activities on social medial cause impulse buying for perishable food items, 
like vegetables, fruits, beef, fish, and among others during the COVID-19 pandemics) with a mean value of 4.034, received the least emphasis on the statements surveyed. This is so because, based on the personal interview, most women during the lockdown and the pandemic were not interested in impulse buying, but rather concentrated on buying the basic needs and wants using before the pandemic for the up keeping of the family. Hence, promotional activities on social media rarely cause any impulse buying during the pandemic and lockdown. The customer's economic power and needs determine the online purchase decision.

\section{B. The Test of Research Hypotheses}

Research Hypothesis One - $\mathbf{H}_{0}$ : Promotional activities on social medial have no significant influence on purchase choice decisions for perishable food items, like vegetables, fruits, beef, fish, and among others during the COVID-19 pandemics.

From the mean column in table I, it can be seen thatA1: Promotional activities on social medial have a significant influence on purchase choice decisions for perishable food items, like vegetables, fruits, beef, fish, and among others during the COVID-19 pandemics saw a certain level of degree of acceptance, with the mean value of 4.047, in this way, experiencing encouraging low support for the research question. Also, giving to the data collected, $76.20 \%$ of the women do not agree that promotional activities have a significant influence on purchase decisions for perishable food items, like vegetables and others. While $23.80 \%$ of the women questioned claimed that it did. During the pandemic, women are more interested in buying the family's needs and wants, and not necessarily based on promotional activities influence. Therefore, the null hypothesis is hereby accepted that "Promotional activities on social medial have no significant influence on purchase choice decision for perishable food items, like vegetables, fruits, beef, fish, and among others during the COVID-19 pandemics".

Likewise, in the t-test analysis (not recorded here), when tested at a 5 percent level of significance, the $t$ score values $=$ 1.46. Since the $\mathrm{t}$ score value is less than the $\mathrm{t}$ - table value of 1.96, therefore the null hypothesis is accepted and the alternative hypothesis is hereby rejected, interpreted also to mean that Promotional activities on social medial have no significant influence on purchase choice decisions for perishable food items, like vegetables, fruits, beef, fish, and among others during the COVID-19 pandemics. Hence, the null hypothesis $\left(\mathbf{H}_{\mathbf{0}}\right)$ is hereby accepted.

Research Hypothesis Two - $\mathbf{H}_{0} 2$ : Promotional activities on social medial do not have a significant influence on impulse buying for perishable food items, like vegetables, fruits, beef, fish, and others during the COVID-19 pandemics.

From the mean column in table I, it can be seen that A2: (Promotional activities on social medial cause impulse buying for perishable food items, like vegetables, fruits, beef, fish, and among others during the COVID-19 pandemic) saw mean value 4.034, experiencing least support for the research questions asked.

Likewise, data collected indicated that $64 \%$ of the women supported the question by saying only once a while, and $36 \%$ said not at all. This result is supported by extant literature. From this research, it can be generalized that most of the women during the pandemic behaved like the concerned consumers or rational consumers as in extant literature, who planned their spending carefully, remain loyal to certain brands, not behave on impulse, and are not risk-averse, with their behavior remaining unchanged [2].

Likewise, in the t-test analysis (not recorded here), when tested at a 5 percent level of significance, the t- score values for $\mathrm{A} 2=1.329$. Since the $\mathrm{t}$ score value is less than the $\mathrm{t}$ table value of 1.96 , therefore the null hypothesis is hereby accepted that "Ho: Promotional activities on social medial do not have a significant influence on impulse buying for perishable food items, like vegetables, fruits, beef, fish, and among others, during COVID-19 pandemic, and the alternative hypothesis that " $\mathbf{H}_{1}$ : Promotional activities on social medial do have a significant influence on impulse buying for perishable food items, like vegetables, fruits, beef, fish, and among others, during COVID-19 is hereby rejected.

Research Hypothesis Three $-\mathrm{H}_{0}$ : Promotional activities on social medial have no significant influence on the price for perishable food items, like vegetables, fruits, beef, fish, and others during the COVID-19 pandemics.

From the mean column in table I, it can be seen that A4 (A4: Promotional activities on social medial has a significant influence on the purchase price for perishable food items, like vegetables, fruits, beef, fish, and among others during the COVID-19 pandemic), witnessed some level of degree with mean value, 4.792 so, experiencing some support for the research question. Also, A3 (A3: Promotional activities on social media have a significant effect on the price of food items during the COVID-19 pandemics) witnessed some level degree of mean value 4.662, so, experiencing encouraging support for the research question.

Likewise, data collected indicated the women supported the questions by saying sometimes $58 \%$ and $42 \%$ says fairly often.

Likewise, in the t-test analysis (not recorded here), when tested at a 5 percent level of significance, the $t$ score values = 2.30. Since the $t$ score value is higher than the $\mathrm{t}$ - table value of 1.96, therefore the null hypothesis is rejected and the alternative hypothesis that "- $\mathbf{H}_{\mathbf{1}}$ : Promotional activities on social medial has a significant influence on the purchase price for perishable food items, like vegetables, fruits, beef, fish, and among others during COVID-19, is hereby accepted.

Research Hypothesis Four $-\mathbf{H}_{0}$ : There are no significant differences between the original market price of goods before the COVID-19 pandemic and the promotional online prices during the pandemic

From the mean column in table I, it can be seen thatA5 (A5: There are significant differences between the original market price of goods before the COVID-19 pandemic and the promotional online prices during the pandemic), witnessed encouraging degree of mean value 6.241, so, experiencing encouraging support for the research question. Likewise, data collected indicated that, women supported the questions by $100 \%$ of them saying "Frequently, if not always".

Likewise, in the t-test analysis (not recorded here), when tested at a 5 percent level of significance, the $\mathrm{t}$ score values = 4.16. Since the $t$ score value is higher than the $t$ - table value of 1.96, therefore the null hypothesis is rejected, and the alternative hypothesis that "- $\mathrm{H} 1$ : There are significant differences between the original market price of goods before 
the COVID - 19 pandemic and the promotional online prices during the pandemic is hereby accepted.

Research Hypothesis Five - $\mathbf{H}_{0}$ : The online price of delivering goods to consumer homes does not have a significant influence on consumer quantity purchase decisions during the COVID-19 pandemics.

From the mean column in table I, it can be seen that A6 (A6: Online price of bringing goods to consumer homes influence consumer quantity purchase decision) saw mean value 4.913 experiencing some level of support for the research questions asked.

Likewise, data collected indicated that $91 \%$ of the women supported the question by saying sometimes, and $9 \%$ said fairly often. Likewise, in the t-test analysis (not recorded here), when tested at a 5 percent level of significance, the tscore values for $\mathrm{A} 2=3.217$. Since the $\mathrm{t}$ score value is more than the t table value of 1.96 , therefore the null hypothesis is hereby rejected, and the alternative hypothesis that " $\mathbf{H}_{\mathbf{1}}$ : Online price of bringing goods to consumer homes does have a significant influence on consumer quantity purchase decision during COVID-19 is hereby accepted.

Research Hypothesis Six - $\mathbf{H}_{0}$ : There is no significant relationship between consumer location and the online price of goods during the COVID-19 pandemics.

From the mean column in table I, it can be seen that A7 (A7: There are significant relationship between consumer location and the online price of goods during the COVID-19 pandemics) witnessed an encouraging degree of mean value, 5.136, so, experiencing encouraging support for the research question

Also, giving to the data collected, $96.20 \%$ of the women do not agree that there is any significant relationship between consumer location and the online price of goods during the COVID-19 pandemics. Therefore, the null hypothesis is hereby accepted that there is no significant relationship between consumer location and price of goods during the COVID-19 pandemics.

Likewise, in the t-test analysis (not recorded here), when tested at a 5 percent level of significance, the $t$ score values $=$ 1.62. Since the $\mathrm{t}$ score value is less than the $\mathrm{t}$ - table value of 1.96 , therefore the null hypothesis is accepted, and the alternative hypothesis is hereby rejected.

Research Hypothesis Seven - Ho: There are no significant relationship differences between consumer location and delivery price during the COVID-19 pandemics.

From the mean column in Table I, it can be seen that A8 (A8: There are significant differences between consumer location and delivery price during the COVID-19 pandemics) witnessed encouraging degree of mean value, 5.582, so, experiencing encouraging support for the research question.

Likewise, data collected indicated that the women supported the questions by $97 \%$ of them fully supporting the question, while only $3 \%$ did not fully support the question. Likewise, in the t-test analysis (not recorded here), when tested at a 5 percent level of significance, the $t$ score values $=$ 3.79. Since the $\mathrm{t}$ score value is higher than the $\mathrm{T}$ - table value of 1.96 , therefore the null hypothesis is rejected and the alternative hypothesis that "- $\mathbf{H}_{1}$ : There are significant relationship differences between consumer location and delivery price during the COVID-19 pandemics "is hereby accepted.

\section{CONCLUSION AND SUGGESTIONS FOR FURTHER RESEARCH}

This study has investigated if social media promotional activities have an influence on purchase choice decisions and price of perishable food items during COVID-19 in Lagos, Nigeria, with a special focus on women as a case study.

From the study, data revealed that social media promotional activities do have some level of influence, but not a strong influence on the purchase choice decision of perishable food items during the COVID-19 pandemics. Investigation showed that during the crisis, like that of COVID-19, families focus on needs and wants that they had already formed the habit of having before, and not crave for new adventures. Most women purchase based on family needs. From the study, it is clear the women already know the food items they want to buy, because most women are knowledgeable about their family needs, and are often online using social media to gather information about where to find their desired needs and wants.

This also indicates that women only buy well-known food items if they can afford them since they are aware of the quality or perhaps have a good experience of the food items already. The study results also show promotional activities on social media for perishable food items during the pandemic does not necessarily influence consumers purchase choice decision, but rather to some extent influence consumer quantity purchase. And there is a difference between the original market price of goods before the COVID-19 pandemic and the promotional online price during the pandemic. Likewise, there is a relationship between consumer location and price of goods delivery during the COVID-19 pandemics. The findings of the study showcase a typical situation of things during crisis in a developing country, where people take advantage of situations to exploit the helpless. Prices of goods increased, and people had no choice but had to buy because man cannot do without food.

\section{FUTURE RESEARCH SCOPE}

This study was limited to women in Lagos State, Nigeria. This theme can be extended to other women in other states in Nigeria, but not necessarily in the cities alone. Further research can also be conducted on a large scale with a large sample size considering some more variables relevant to the topic.

The study confined itself to 76 usable respondents' questionnaires from women in the Lagos States, compared to the total number of 36 states, plus federal capital territory Abuja in Nigeria. This research, therefore, should be replicated in more states and more women in Nigeria. In this way, the findings may not be a thorough reflection of the views of women in Nigeria as a whole.

These results may be useful to both academics and business practitioners with an interest in the Nigerian economy.

\section{REFERENCES}

[1] J. Sheth, "Impact of Covid-19 on consumer behavior: Will the old habits return or die?" Journal of Business Research, Elsevier, vol. 117(C), pp. 280-283, $4^{\text {th }}$ June, 2020. 
[2] P. Amalia, and P. Ionut, Consumers reaction and organizational response in a crisis context, Uni. Of Oradea. The Journal of the Faculty of Economics, vol. 1, no. 5, pp. 779 - 782, May, 2009.

[3] M. Cogley, Has social media turbocharged panic buying by UK shoppers? https://www.telegraph.co.uk/technology/2020/03/10/hassocial-media-turbocharged-panic-buying-uk-shoppers, March, 2020.

[4] F. Mao, "Coronavirus panic: why are people stockpiling toilet paper?" https://www.bbc.co.uk/news/world-australia-51731422, $4^{\text {th }}$ March, 2020.

[5] A. A Alalwan, "Investigating the impact of social media advertising features on customer purchase intention" Int, Inf. Manag, vol. 42, pp $65-77,5^{\text {th }}$ June, 2018.

[6] A. A. Alalwan, R. S. Algharabat, A. M. Baabdullah, N. P. Rana, R. Raman, R, Dwivedi and A. Aljafari "Examining the impact of social commerce dimensions on customers' value cocreation: the mediating effect of social trust," Journal of Consumer Behaviour vol. 18, no. 6, pp. 431-446, 27 $7^{\text {th }}$ December, 2019.

[7] Q. P. A. Baker, F. Murtaza, and A.G. Kazi, "The impact of social media on impulse buying behavior in Hyderabad Sindh Pakistan," International Journal of Entrepreneurial Research, vol. 2, no. 2, pp. 8 $12,13^{\text {th }}$ May, 2019.

[8] A. A. Alalwan, N. P. Rana, Y. K. Dwivedi, and R. Algharabat, "Social Media in Marketing: A Review and Analysis of the Existing Literature," Telematics and Informatics (2017), doi: http://dx.doi.org/10.1016/j.tele.2017.05.008.

[9] A. A. Alalwan, "Mobile food ordering apps: an empirical study of the factors affecting customer e-satisfaction and continued intention to reuse," Int. J. Inf. Manag, vol. 50, pp. 28-44, February, 2020.

[10] N. Shaw, "Supermarket sites collapse as people rush to book deliveries," https://www.walesonline.co.uk/news/uknews/supermarket-sites-collapse-people-rush-17968808, 21 $1^{\text {st }}$ March, 2020.

[11] R. Zheng, B. Shou, and J. Yang. (March, 2020) Supply disruption management under consumer panic buying and social learning effects,

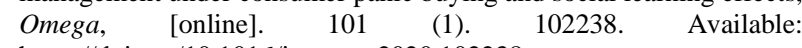
https://doi.org/10.1016/j.omega.2020.102238.

[12] B. Frank, and S. J. Schvaneveldt, "Understanding consumer reactions to product contamination risks after national disasters: the roles of knowledge, experience, and information sources" Journal of Retailing and Consumer Services, vol. 28, pp. 199-208, January, 2016.

[13] Sveriges Television. "Frukt och grönsaker kan bli dyrare framöver" Retrieved from SVT Nyheter: https://www.svt.se/nyheter/lokalt/jonkoping/frukt-och-gronsaker-kanbli-dyrareframover, 22 ${ }^{\text {nd }}$ April, 2020c.

[14] R. Leggett, "Quality and Efficacy May Beat out Price Sensitivities amid Coronavirus Concerns," Retrieved from Nielsen: https://nielseniq.com/global/en/insights/analysis/2020/quality-andefficacy-may-beat-out-price-sensitivities-amid-coronavirus-concerns, March, 2020b.

[15] P. Sans, G. De Fontguyon, and G. Giraud, "Value-based labels for fresh beef: an overview of French consumer behavior in a BSE crises context" International Journal of Consumer Studies, vol. 32, no. 5, 407-413, September, 2008.

[16] G. Theodoridou, E. Tsakiridou, N. Kalogeras, and K. Mattas. (June, 2019). The Impact of the Economic Crisis on Greek Consumer Behaviour towards Food Consumption, International Journal on Food System Dynamics, [online]. 10 (3). pp. 298-314. Available: https://dx.doi.org/10.18461/ijfsd.v10i2.20.

[17] J. Harvey, G. Erdos, S. Challinor, S. Drew, S. Taylor, R. Ash, S. Ward, C. Gibson, C. Scarr, F. Dixon, and A. Hinde, "The relationship between attitudes, demographic factors and perceived consumption of meats and other proteins in relation to the BSE crisis: a regional study in the United Kingdom" Health, Risk \& Society, vol. 3, no. 2, pp. 181-197, 14 June, 2010.

[18] C. Arnade, L. Calvin, and F. Kuchler, Consumer response to a food safety shock: the 2006 food-borne illness outbreak of E. coli O157: H7 linked to spinach. Review of Agricultural Economics, vol. 31, no. 4, pp. 734-750, December, 2009.

[19] J. Rieger, D. Weible, and S. Anders, "Why some consumers don't care: Heterogeneity in household responses to a food scandal," Journal homepage: www.elsevier.com/locate/appet Appetite, vol. 113, vol. 1, 200-214, $1^{\text {st }}$ March, 2017.

[20] Riksbanken, "The Riksbank's measures during the coronavirus pandemic," Retrieved from Riksbanken: https://www.riksbank.se/globalassets/media/rapporter/fsr/fordjupning ar/engelska/2020/2025/ the-Riksbank's-measures-during-thecoronavirus-pandemic-article-in-thefinancial-stability-report-2020_1. pdf, 2020.

[21] M. Canfranc, "From the Great Recession to the Great Pandemic: the differences between the 2008 and 2020 crises" Retrieved from BBVA https://www.bbva.com/en/from-the-great-recession-to-the-greatpandemic-thedifferences-between-the-2008-and-2020-crises, April, 2020.

[22] T. Newman, "Comparing COVID-19 with previous pandemics" Retrieved from Medical News Today: https://www.medicalnewstoday.com/articles/comparing-covid-19with-previous-pandemics, $19^{\text {th }}$ April, 2020.

[23] BBC. "Coronavirus: 'One billion could become infected worldwide report" Retrieved from BBC: https://www.bbc.com/news/world52453640, 28 ${ }^{\text {th }}$ April, 2020a.

[24] U. Aslam, F. Muqadas, M. K. Imran, and A. Saboor, "Emerging organizational parameters and their roles in the implementation of organizational change," Journal of Organ. Change Management, vol. 31 , no. 4 , pp. $1084-1104,11^{\text {th }}$ July, 2018.

[25] L. T. Cronbach, "Test reliability: its meanings and determination," Psychometrical, vol. 12, no. 1, pp. 1-16, March, 1947.

[26] R. Berger, "This Crisis Is Different - Comparing The Coronavirus Crisis With The Financial Crash" Retrieved from Rolandberger: https://www.rolandberger.com/en/Point-of-View/Point-of-ViewDetails_65664.html, $24^{\text {th }}$ April, 2020.

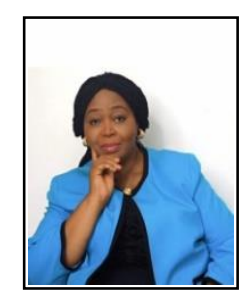

Udegbe Scholastica Ebarefimia - Contemporary Business Issues Academic Research Group, Lagos, Nigeria. Ph.D. International Business, from Lagos State University. Nigeria. Ph.D. Geography and Regional Planning (Agricultural Geography) from Ambrose Alli University, Nigeria.

M.Sc. Business Administration (marketing) and B.Sc Business Administration - both from the University of Lagos. Nigeria. Fellow of the Institute of Management Consultants, Fellow of National Institute of Marketing of Nigeria, A member of the Institute of Strategic Management of Nigeria.

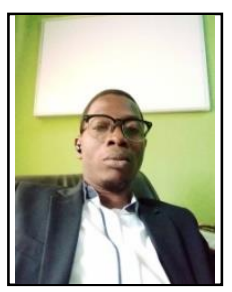

Adekunle Azeez Aliu is a Lecturer in the Department of Marketing, the Federal Polytechnic, Ilaro. Prior to joining FPI in 2014, Mr. Aliu was a Lecturer in the Department of Marketing at Lagos State University (LASU), Ojo from 2009 and the Examination Officer from 2011 to 2014. He holds a B.Sc. (Hons) degree in Marketing from Lagos State University, main campus Ojo with a second class Upper division and M.Sc. degree in Marketing from University of Lagos, Akoka. He holds National Diploma in Banking and Finance from the Federal Polytechnic, Ilaro, he is a member of National Institute of Marketing (NIMN) and also a member of Institute of Business Strategy (IBS). Mr. Aliu is a Cisco certified and he is an instructor in Cisco academy. He has taught Marketing Environment, Marketing Management, Retail Management, Distribution and Logistics Management, Sales Management, E-marketing, Product management \& Development, Marketing Planning \& Control, Hospitality Marketing Management, and Research Methodology at University and Polytechnic levels in the last ten years. He has published a number of scholarly articles and co-author of books in the areas of Marketing and entrepreneurship. He hails from Ipokia Local Government, Ogun State, Nigeria. 